This item was submitted to Loughborough's Research Repository by the author.

Items in Figshare are protected by copyright, with all rights reserved, unless otherwise indicated.

\title{
The screams all sound the same : the music of Of Monsters and Men and the Icelandic imaginary as geographical discourse
}

\section{PLEASE CITE THE PUBLISHED VERSION}

https://doi.org/10.1111/area.12422

\section{PUBLISHER}

(C) 2018 Royal Geographical Society (with the Institute of British Geographers). Published by Wiley

\section{VERSION}

AM (Accepted Manuscript)

\section{PUBLISHER STATEMENT}

This is the peer reviewed version of the following article: TWEED, F. and WATSON, A., 2018. The screams all sound the same : the music of Of Monsters and Men and the Icelandic imaginary as geographical discourse. Area, 51 (1), pp.126-133, which has been published in final form at https://doi.org/10.1111/area.12422. This article may be used for non-commercial purposes in accordance with Wiley Terms and Conditions for Use of Self-Archived Versions.

\section{LICENCE}

CC BY-NC-ND 4.0

\section{REPOSITORY RECORD}

Tweed, Fiona, and Allan Watson. 2018. "The Screams All Sound the Same : The Music of of Monsters and Men and the Icelandic Imaginary as Geographical Discourse". figshare. https://hdl.handle.net/2134/27796. 


\title{
The screams all sound the same ${ }^{1}$ : the music of Of Monsters and Men and the Icelandic imaginary as geographical discourse
}

\begin{abstract}
Over the last two decades, a substantial body of geographical research has emerged examining the mutually generative relations between music, space, place, landscape, identity and locality. This work has revealed the complex ways in which specific geographical identities and imaginaries can be reinforced and created through differences in sound, through lyrics, and through the acts and meanings of making music. Yet, these identities and imaginaries can also perform important economic functions, representing geographical discourses that musicians can employ to develop distinctiveness to make themselves marketable, particularly in the context of a heavily-saturated contemporary global music market. In this paper, we examine this with specific relation to the Icelandic band, Of Monsters and Men. We provide an account of how references to landscape and folklore in the band's music, lyrics and imagery represent not only expressions of intimate connections with local landscape, cultural identity and lived experience, but also embody awareness of a pre-existing Icelandic imaginary. The use of folk music instruments, cultural references and motifs, we argue, acts to legitimise the band's use of this imaginary. Further, we highlight explicit attempts to brand Icelandic music under a single 'label' as representative of the way in which this Icelandic imaginary comes to represent a powerful, if potentially homogenising, geographical discourse to mark out Icelandic music in a crowded global music market.
\end{abstract}

\footnotetext{
${ }^{1}$ The title of this paper is borrowed from the lyrics of the Of Monsters and Men song Little Talks, featured on the album My Head is an Animal released internationally on Republic Records on $3^{\text {rd }}$ April 2012.
} 


\section{Introduction: music, place and geographical imaginaries}

During a short period in the second half of the 1990s, a series of key articles emerged calling for the relationships between music, space, place, landscape, identity and locality to be explored in greater depth (see Smith 1994, 1997; Leyshon et al. 1995; Kong 1995; Cohen 1995; Halfacree and Kitchin 1996). These articles would prove to be agenda-setting in creating a new sub-disciplinary area of enquiry on the geographies of music and in the two decades since, a significant body of work has developed, both from within and beyond the discipline of Geography, which has critically considered the mutually-generative relations of music and place (see Connell and Gibson 2003, for a comprehensive overview of key issues). Amongst many other examples, one can refer to the work of Forman (2000) on race, space and place in rap music; Connell and Gibson (2004) on world music; Gibson and Davidson (2004) on country music in Tamworth, Australia; Revill (2005) on vernacular culture and the place of folk music; Hudson (2006) on regions, music and identity; Harrison (2010) on heavy metal in Birmingham, UK; Nevarez's (2013) critical account of Joy Division and the 'sound' of Manchester, UK; and Ballico (2016) on indie pop/rock in Perth, Australia.

As Hubbard (2010) argues, artists often make much of the ways in which their music speaks of particular experiences and spaces. This acknowledgement of place within music and lyrics is often part of the conscious assertion (or sometimes rejection) of specific geographical identities (Leyshon et al. 1995) and particular 'geographical imaginaries', reinforced through differences in sound, through lyrics, and through the act of music-making. The notion of a 'geographical imagination', Daniels suggests, has become part of the lexicon of human geography and has "conventionally taken up a location somewhere between the domains of the factual and fictional, the subjective and objective, the real and representational" $(2011,182)$. In the case of music, the production of a geographical imaginary, that is to say a particular perception of a place, may draw both upon real and imagined notions and symbols of identity, culture and landscape. Examining music and English nationalism at the turn of the $20^{\text {th }}$ Century, for example, Revill (2000) explores how 'pastoral' music, such as that of English composer Vaughan Williams, drew on folk songs to make reference to specific locations and landscapes, and concludes that this music was indicative of the complex relationship between land and landscape, and nature and culture, and was tied to imagined notions of England's national identity. Such imaginative geographies are also produced at 
the nexus of real, mundane everyday experience of place and the mythical and fantastical (Gregory 1995; Daniels 2011). Mitchell's $(2009,2013)$ work on Icelandic music and landscape for example, considers the music of artists such as Sigur Rós and Björk as being grounded in Icelandic geography and culture, but also as creating sonic expressions of Iceland's dramatic physical landscape. The perceptions of this landscape that are drawn upon are in part real and in part imagined and fantastical; Mitchell argues that the music acts to "transport listeners into an imaginary world" $(2009,172)$ as part of the development of an 'Icelandic imaginary' (see also Webb and Lynch 2010). From an ontological perspective, we consider the geographical imaginary as being affective, that is to say creating or evoking particular emotions about a place; and at the same time a matter of discursive, aural and/or aesthetic practice, that is to say a particular way of representing and communicating the real or imagined qualities of particular places. Following the seminal work of YiFu Tuan $(1979,409)$ one can think of these two aspects as being inter-subjective, with the geographical imaginary evoking a 'spirit' or 'personality' of place. Tuan argues that the personality of a place is developed through a prolonged interaction between humans and nature, and gives places a particular 'emotional charge' - with elements of both awe and affection - and lending them a unique 'signature'. The idea of a geographical imaginary then draws us back to the origins of the term in Edward Said's Orientalism (1978), in that it arguably acts to exoticise and 'other' Iceland, situated in the context of broader imaginings of 'the North' (Davidson 2005).

In this paper, we develop and critique this notion of an 'Icelandic imaginary' to consider how not only is it rooted in the local and shaped by Icelanders (Oslund 2002), but also how it has become globalised as part of an international commercialisation of Icelandic cultural products, especially through music. In particular, we consider how the overt connections drawn between place and music by Icelandic artists are often set within the context of a saturated global music market, in which they must develop an identity in order to make themselves marketable. As Connell and Gibson (2003) emphasise, commercial success often revolves around geographical discourses, with music from unique locations being marked out as innovative and different. Thus, in particular genres at particular times, certain locations have become highly marketable commodities. Indeed, Prior $(2015,94)$ notes how "scenes themselves and their myths are a circulating idea or commodity" in which distinctive cultural goods are a resource deployed by 
nations in "the battle for attention" and in the establishment of a cultural economy. In this paper, we examine this in relation to the development of an 'Icelandic imaginary' centred on particular notions and perceptions of Icelandic landscape and folklore. Specifically, we consider how this imaginary has come to be represented in the music of the Icelandic band Of Monsters and Men. We provide an account of how references to landscape and folklore in the band's music, lyrics and imagery embody not only expressions of intimate connections with local landscape and lived experience, but also represent an acute awareness of a pre-existing Icelandic imaginary that holds significant marketing power. This imaginary has thus come to represent a geographical discourse, which distinguishes Icelandic music in a crowded global music market.

\section{Icelandic landscape, cultural identity and music}

In order to set the context for our subsequent discussion of Of Monsters and Men, we first provide a very brief characterisation of the landscape of Iceland with specific reference to the links between Icelandic landscape, folklore and cultural identity. Landscape and the idea of 'North' have been significant influences on the development of Icelandic nationalism and national identity, especially over the last 300 years (see Davidson 2005; also Ísleifsson and Chartier 2011). An island outpost in the north Atlantic, Iceland has a history of relative isolation, which is widely considered to contribute to the Icelanders' particular relationship with their landscape (e.g. Zarilli 2011). It is this relationship that we consider here.

The transmission of history and literature from one generation to the next is common to many societies and plays a part in how aspects of culture are embedded and constructed in place. Icelanders maintain a strong connection with ancient traditions to preserve a distinct Icelandic identity. Iceland is revered for its written literature and the tradition of story-telling owes some of its origins to the famous saga literature (Íslendingasögur) a form of prose history describing the challenges of Iceland's early settlers in the tenth and eleventh centuries. It is likely that these stories were first transmitted as oral histories, but scholars emphasise the importance of the authors who wrote them down, marking the transition from tradition to literature (e.g. Mundal and Wellendorf 2008). Hreinsson (2013) suggests that such story-telling is fixed in this 'settler society' 
and emerges from the need to create a myth of identity and collective memory. The geographical reach of the sagas is wide, but most of them centre on real and familiar Icelandic territory, firmly rooting them in place.

Geophysical processes exert a profound influence on the Icelandic landscape and the volatility and unpredictability of the environment is evident in mythology and folklore, which is deeply embedded in Icelandic history and culture. As Tuan (1979) suggests, the 'spirit' of a place can be taken in a literal sense, with space formless and profane except for the sites that 'stand out' because spirits are believed to dwell in them. Icelandic culture is imbued with folk legends, which are attached to real places and people, and fictional 'wonder tales'. These stories have been passed down through the generations and refer to supernatural beings such as trolls, elves, changelings, ghosts and water dwellers. Tales of elves or the hidden folk (huldufólk) have been commonplace in Iceland for centuries and can be traced back to pagan Scandinavian mythology (Simpson 2004). The need for co-existence between elves and humans is often emphasised and this ultimately connects to the landscape; huldufólk are regarded as an intrinsic component of the natural environment, their primary concern being to protect their surroundings. Strmiska $(2000,126)$ contends that the huldufólk are "not so much supernatural as ultranatural" in that they represent a "deep reverence" for the land and the Icelanders' affinity with their environment, rather than the conquest of nature. Such stories and legends give people strong cultural bonds with place; Neijmann (1997) observes that belief in supernatural creatures is geographically-bound, while Tuan $(1991,686)$ suggests that such myths, "by weaving in the landscape (a tree here, a rock there), strengthen a people's bond to place". Manganelli $(2006,86)$ states that Icelanders' lives are "represented by how they relate to the incredible land on which they live" and the bond formed between people and place, or topophilia, is intense. Benedikz $(1973,2)$ comments that it is unsurprising that the power of imagination is strong "when one's life is conditioned by a landscape dominated by rocks twisted by volcanic action, wind and water into ferocious and alarming shapes".

It is common amongst popular music reviewers and critics, as well as academics, to draw links between Iceland's dramatic landscape and the music of its performers: as Sullivan $(2003,122)$ notes, "It has become a cliché to describe Icelandic music in terms of its environment, although it is tempting at times, no matter how hard you try and resist." Indeed, such links are often explicit and 
intentional on the part of artists; for example in Jón Leifs' compositions based on Icelandic topographical features; or Kaleo's live performance of Way Down We Go in a volcano (https://www.youtube.com/watch?v=9WIU5NN1Q0g) and of Save Yourself live from an iceberg at Fjallsárlón Glacier Lagoon (https://www.youtube.com/watch?v=oCiORHLrauU). Iceland's most famous musical export, Björk (1997), describes Iceland as a nation in which "everything revolves around nature, 24 hours a day. Earthquakes, snowstorms, rain, ice, volcanic eruptions, geysers... very elemental and uncontrollable." She has drawn heavily on the Icelandic landscape and its agents of change in her music, even translating volcanic activity into sound in her third album, Homogenic (Sullivan 2003; Mitchell 2013). Her wish was that the album should capture Iceland's geography and sound like "rough volcanoes with soft moss growing over it" (Barton 2015).

Even where the relationships between landscape and music are not explicit on the part of the performer, they are frequently inferred. Mitchell (2009), for example, interprets the music of Sigur Rós as a sonic expression of isolation, creating "geomorphic soundscapes which transport listeners into an imaginary world" $(2009,172)$ and metaphorically evoking "glacial shifts or the contours of craggy hills" $(2009,181)$. Their music, he suggests, provides the listener with a sonic and visual expression of an Icelandic imaginary. In the case of Björk, Icelandic nationality has been used as a metaphor for the extremes of both her music and her identity, which Dibben (2006) takes to represent the 'fire and ice' of her home country. Mitchell (2013) remarks that Björk's music is predominantly perceived as "elemental, ethereal and geomorphic, deeply grounded in Icelandic geography and culture" $(2013,48)$.

As Prior $(2015,84)$ notes, the "romantic exaltation" of natural beauty in the context of Iceland is tied to the assumptions that its music "could not have come from anywhere else but the rousing wastes and wilds of its landscape" and that a relational affinity exists between the natural environment and autochthonous creativity. Beyond Iceland, this perceived relationship between a very particular and novel musical aesthetic and a unique landscape has become central to the development of a globalised 'Icelandic imaginary'. The commercial success of artists such as Björk is intimately tied to this imaginary, both in terms of how the music is perceived and interpreted by audiences, and, as we shall emphasise later, the power of this imaginary as a resource for marketing. However, the drawing of such associations between landscape, nature and music may at 
times be unwelcome, especially for emerging artists whose music and identity will be judged against imaginations and stereotypes (many based around Björk) of what it is to be 'Icelandic'. This can make it difficult for Icelandic bands to create their own 'novel' identity. At best, when asked the inevitable questions about the impact that nature has had on their music, many Icelandic musicians find it a difficult issue to talk about (Sullivan 2003). Yet, it is certainly the case that playing, in more or less explicit or conscious ways, on Icelandic identity can contribute positively to commercial success.

\section{Of Monsters and Men and the global Icelandic imaginary}

The recent and global commercial achievements of the band Of Monsters and Men provide a case in point. The band emerged onto the international music scene to critical acclaim in 2011 with their debut album My Head is an Animal, having won Músíktilraunir, an Icelandic annual battle of the bands competition, the year before. My Head Is an Animal was a chart number 1 in Australia, Iceland and Ireland and reached number 6 on the US Billboard 200 album chart and number 3 in the UK. The single Little Talks was an international hit, reaching the Top 10 of most music charts in Europe; it was named Alternative Song of the Year by iTunes UK in 2012. Their second album Beneath the Skin was released in 2015, and debuted at number 3 on the US Billboard 200 album chart.

Associations between the music of $O f$ Monsters and Men and Icelandic natural landscapes abound in the popular music press. In a 2015 review of the album Beneath the Skin, for example, Bickers states that: "“Thousand Eyes" is perhaps the most Icelandic sounding track on the album. Opening with the soft trickle of flowing water and vocals enhanced with an ethereal echo, the song sounds like it could literally have been recorded in a cave in the side of a mountain". While Mitchell (2013) suggests that there is some resistance amongst musicians in Iceland to the localisation of their work, in the case of Of Monsters and Men recognition is given by the band to the role of Icelandic landscape and cultural history. For example, Ragnar Pórhallsson, singer in the band, acknowledges the "special atmosphere that often comes with Icelandic music, an atmosphere that is created by living in Iceland and I think that nature plays a large role" (Baldursdóttir 2014). In 
another interview in 2015 the band, when asked by the interviewer about the relationship between their music and the "nature and divinity of Iceland", recognised that "growing up in Iceland has definitely influenced our writing", but noted that "it's not that we set out to use nature and scenery in our lyrics, it's more that it just happens. I guess the things you grow up with kind of linger in your head and pop up later when you're searching for inspiration" (Aboushaca 2015).

The inspiration that is drawn from Icelandic folklore is one of the most distinctive elements of the music, lyrics and imagery of Of Monsters and Men. Members of the band have discussed this openly in interviews: "We write the songs together," Raggi explains, "and we found we could bond better by telling each other fairy tales than writing about real life" Mossman (2012). Bassist Kristján Páll Kristjánsson, describes the nature of these stories as "old national stories that have been kept for hundreds of years that we are always told as children. Stories of elves and trolls and weird stuff happening, so we are kind of used to that, and that is probably why we are used to these storytelling lyrics" (Chambers 2013). Throughout the album My Head is an Animal, there are lyrical references to fairy-tale creatures: monsters, ghosts, wolves and other animals and, associated with these, fear, screaming, shadows and running. This is exemplified in lyrics such as: "Howling ghosts they reappear, in mountains that are stacked with fear" (King and Lionheart); "All the monsters in my head, and I move slow and steady, but I feel like a waterfall (Slow and Steady); and "Somewhere deep in the dark, howling beast hears us talk, I dare you to close your eyes... The earth is shaking and I see a light" (Yellow Light). These references are also made visually: for example, in the video for the song Little Talks (https://www.youtube.com/watch?v=ghb6eDopW8I) mountains take on the form of giant creatures; while the video for Dirty Paws (https://www.youtube.com/watch?v=mCHUw7ACS80) focuses on the journey of a large furry being through an icy volcanic landscape. Benedikz $(1973,7)$ notes how with long winters, darkness is a dominant feature of life and that "Darkness is in any case a powerful instigator of nervous tension... it can surprise no-one that creatures of the dark have flourished abundantly in Iceland", while Nanna from the band describes such songs as being about "irrational fears" (Lanham 2016).

Further, given that Iceland is an isolated island surrounded by the Atlantic, as Benedikz $(1973,3)$ suggests, "the sea has provided Icelandic folklegend [sic] with a vast number of stories". The sea and water feature prominently in the band's lyrics on My Head is an Animal, with 
references to waves, drowning and boats in many songs. The lyrics of Little Talks for example, develop a metaphor around a ship as a vehicle of safe deliverance. The video for Love Love Love (https://www.youtube.com/watch?v=beiPP_MGz6I) shows a Minotaur-like creature in a boat gazing down into the sea, and as the shot widens a sea creature is revealed underneath the boat. One could consider this a reference to the Lagarfljótsormur, which in an interview in 2016, Kristján and Nanna describe as a "really big-ass worm that lives in a lake in Iceland... It's kind of like the Loch Ness monster. Just the Icelandic version of that" (Muhlenberg 2016).

How might one read such references to Icelandic landscape and folklore in the lyrics and imagery of Of Monsters and Men? On the one hand, we might consider it has a form of reassertion of the local; musicians injecting into their music various elements which affirm a sense of local and national identity in the face of homogenising cultural forces (see for example Kong 1997, on popular music in Singapore). In interviews, singer Nanna Hilmarsdóttir emphasises the tradition of storytelling, noting "I grew up on ghost stories a lot, so I'm obsessed with all that kind of stuff. It's definitely where we come from" (Grimes 2015: emphasis added) and "These stories were kind of just around in Iceland but my grandfather told me all these creepy stories when I was a kid and I couldn't get enough" (Khan 2015).

However, as Prior $(2015,82)$ notes, "to reduce the complexity of musical worlds to the immanent or generative qualities of nature is simplistic at best, and damaging at worst". Therefore, we argue that both the band's music and their commercial success must also be considered in the wider context of local and global music industries and markets. As noted previously, playing in more or less explicit or conscious ways on Icelandic identity can contribute positively to commercial success. Not only do Of Monsters and Men draw on previous Icelandic artists like Björk and Sigur Rós as musical and aesthetic references, but also arguably they could not have achieved such commercial success were global audiences not already established by such artists, audiences who are able to interpret these references in the frame of the globalised Icelandic imaginary. The label 'Icelandic' is perhaps unique in musical terms, in that it allows for both for the creation of distinction in the marketplace and the signalling of innovation, but also at the same time draws on cultural references with which a global audience has become familiar. 
The success of the band must also be viewed in the context of two other aspects of the globalised music industry. First, in the late 2000s there developed what became loosely termed a transnational 'folk music' scene across North America and Europe. This scene consisted of a number of bands that could be considered mainstream acts, but who played traditional folk music instruments and drew on folk motifs. As Chambers (2013) notes in her review of My Head is an Animal, "With a unique assortment of instruments that includes everything from accordion to glockenspiel, the band has been compared to the likes of Edward Sharpe and the Magnetic Zeros [from Los Angeles], Mumford and Sons [from London] and Arcade Fire [from Montreal]". However, one might question whether Of Monsters and Men can really be considered a folk band, given both debates around bounded communities and notions of authenticity in folk music theory (Revill 2005) and the traditional positioning of folk music against mass-mediated commercial music (Hill 2007). Yet, this aside, the band has successfully carved a niche and novel identity for themselves within a wider transnational music scene through taking inspiration from Icelandic folklore, fairy tales and landscapes. At the same time, their use of folk music instruments combined with cultural references to the Icelandic imaginary legitimises its use as a geographical discourse for creating distinction in the market.

Second, and more significantly, their success must also be set in the context of a growing Icelandic popular music scene and music industry, and the global marketing of Icelandic music through an "increasingly agile cluster of cultural agencies and intermediaries" (Prior 2015, 83) that have emerged in the capital, Reykjavík. These agencies have been central to the cultural and economic circulation of Icelandic music in broader markets. There is also strong state support for the music industry. Perhaps most significant in this regard was the creation of the governmentsponsored Iceland Music Export (IMX) in 2006, with the explicit aim of increasing the international visibility of Icelandic music, promoting Icelandic musicians and recorded music abroad, and helping businesses and individuals in the Icelandic music industry attain success in foreign music markets (Sigurõardóttir and Young 2011). On their website, IMX explicitly draw upon not only the success of Iceland's established music artists (Of Monsters and Men included), but also the globallyestablished imaginary of Iceland - as small, Northern, isolated and remote - and of its music "superlative" and "eclectic". 
"It's difficult to think of Iceland without thinking of superlative music. From Björk and The Sugarcubes, Sigur Rós, múm and Of Monsters and Men and many other classical, jazz, folk and pop artists, this small and remote North Atlantic nation has caused a stir with the sheer number of acts coming from such a small population $(320,000)$.... The aim is to bring together the disparate strands of Iceland's eclectic music scene under one roof." (http://icelandimusic.is/about, accessed 07/12/2016)

As Prior (2015) notes, Iceland has developed a particular type of cultural capital centred on the 'edgy' and 'alternative'. What we see here is an explicit attempt here to 'brand' the "disparate strands" of Icelandic music under a single label of 'Icelandic', yet in ways that also emphasise the unique characteristics that have been central to creating the global imaginary on which commercial success has centred. In essence, through the activities of IMX and other cultural organisations in Iceland, the global Icelandic imaginary effectively becomes commercialised as a powerful branding and marketing resource. The imaginary thus comes to represent a geographical discourse which marks out the uniqueness of Icelandic music in a crowded global music market, yet at the same time represents a potentially homogenising discourse that may hide uniqueness and variety within vernacular Icelandic music scenes.

\section{Conclusions}

While not all music lends itself readily to geographical interpretation, in some cases artists make much of the ways in which their music speaks of particular experiences and places (Hubbard 2010). In this paper we have sought to demonstrate that, in the case of the Icelandic band Of Monsters and Men, there is clear assertion of a specific geographical identity that draws upon both real and imagined notions of Icelandic identity, folklore and landscape. On the one hand, such expression can be considered as firmly grounded in the local; that is to say a musical expression of lived experience of a particular landscape and a particular cultural setting. Yet, as we have argued, references to folklore and landscape, both lyrically and visually, cannot be seen solely in such 
terms. Rather, the very overt connections that are drawn between place and music in this case must also be considered within the context of a saturated global music market in which musicians must seek to develop a unique identity in order to make themselves marketable, as well as in the context of the active global marketing of Icelandic music.

In this regard, their success must be seen within the emergence of a wider transnational music scene which, through drawing on folk references and playing folk music instruments, has both influenced and legitimised their use of Icelandic folklore and imagined and real landscapes within their lyrics and videos to create a novel identity. But further, we have argued that Of Monsters and Men draw on an established and now globalised Icelandic imaginary. As Tuan (1979) argues places, like humans, acquire unique signatures over the course of time. Iceland's unique signature, at least as perceived by the rest of the world, is we argue deeply attached to this imaginary. Musically speaking, the imaginary finds its origin in the earlier commercial success of Björk and Sigur Ros, who themselves have drawn in explicit ways on Icelandic landscape and identity, yet of course this imaginary has much deeper foundations in notions of 'the North' (Davidson 2005), exoticism, and otherness. Whether one considers their engagement with this imaginary as more or less explicit and more or less intentional, there can be little doubt that the rapid and sustained success of Of Monsters and Men relies to no small degree on the familiarity with, and persistence of, this imaginary amongst consumers in the major music markets of the Western world, and the degree to which this imaginary has been utilised as a geographical discourse to mark out Icelandic music in a crowded global music market.

\section{Acknowledgements}

We are grateful to Peter Kraftl and two anonymous reviewers for their constructive suggestions which have significantly helped to improve this manuscript. 


\section{References}

Aboushaca J 2015 An Interview with Of Monsters And Men: The Melodic Nordic The Aquarian Weekly $23^{\text {rd }}$ September [http://www.theaquarian.com/2015/09/23/an-interview-with-of-monstersand-men-the-melodic-nordic/] Accessed $15^{\text {th }}$ January 2016

Baldursdottír S S 2014 Of Monsters and Men Iceland: the Inside Story Summer ISSN 2298-1926

Ballico C 2016 Another Typical Day in this Typical Town: place as inspiration for music creation and creative expression Australian Geographer DOI: 10.1080/00049182.2016.1223518

Barton L 2015 “Björk on Iceland: 'We don't go to church, we go for a walk'." The Guardian 16th November [http://www.theguardian.com/music/2015/nov/16/bjork-iceland-church-john-grantsigur-ros?CMP=share btn tw] Accessed $3^{\text {rd }}$ December 2015

Benedikz B S 1973 Basic Themes in Icelandic Folklore Folklore 84 1-26

Bickers J 2015 'Beneath The Skin' by Of Monsters and Men Review The Hippo Collective $24^{\text {th }}$ June [http://www.thehippocollective.com/2015/06/24/beneath-the-skin-by-of-monsters-and-menreview/] Accessed $15^{\text {th }}$ January 2016

Björk 2007 “Björk: Albums: Homogenic: Icelandic Techno” Muziekkrant OOR September

Chambers K 2013 “Interview with Of Monsters and Men" Ignition Music Magazine Blog 9 January [http://ignitionstaug.blogspot.co.uk/2013/01/interview-with-of-monsters-and-men.html] Accessed $15^{\text {th }}$ January 2016 
Cohen S 1995 Sounding out the City: Music and the Sensuous Production of Place Transactions of the Institute of British Geographers 20 434-446

Connell J and Gibson C 2003 Sound Tracks: Popular Music, Identity, and Place Routledge

Connell J and Gibson C 2004 World music: deterritorializing place and identity Progress in Human Geography 28 342-361

Daniels S 2011 Geographical imagination Transactions of the Institute of British Geographers 36 $182-187$

Davidson P 2005 The Idea of North Reaktion books London

Dibben N 2006 Subjectivity and the Construction of Emotion in the Music of Björk Music Analysis 25 171-197

Forman M 2000 'Represent': race, space and place in rap music Popular Music 19 65-90

Gibson C and Davidson D 2004 Tamworth, Australia's 'country music capital': place marketing, rurality, and resident reactions Journal of Rural Studies 20 387-404

Gregory D 1995 Imaginative geographies Progress in Human Geography 19 447-485

Grimes 20152015 Of Monsters and Men Explore Their Human Side Interview $6^{\text {th }}$ August [http://www.interviewmagazine.com/music/of-monsters-and-men-grimes\# $]$ Accessed $15^{\text {th }}$ January 2016

Halfacree K H and Kitchen R M 1996 'Madchester Rave on': Placing the Fragments of Popular Music Area 28 47-55 
Harrison L M 2010 Factory music: how the industrial geography and working-class environment of post-war Birmingham fostered the birth of heavy metal Journal of Social History 44 145-158

Hill J 2007 "Global Folk Music" Fusions: The Reification of Transnational Relationships and the Ethics of Cross-Cultural Appropriations in Finnish Contemporary Folk Music Yearbook for Traditional Music $3950-83$

Hreinsson V 2013 Comic Sagas and Tales from Iceland Penguin Classics London

Hubbard P 2010 Darren Hayman \& The Secondary Modern's Pram Town Cultural Geographies in Practice 17 407-414

Hudson R 2006 Regions and place: music, identity and place Progress in Human Geography 30 626634

Ísleifsson S and Chartier D 2011 (Eds.) Iceland and Images of the North Imaginaire Nord Droit au Pôle Series University of Québec, Canada

Khan M 2015 Gimme Your Answers: An Interview w/ Of Monsters and Men. A Music Blog, Yea? $12^{\text {th }}$ November [http://amusicblogyea.com/2015/11/12/gimme-your-answers-an-interview-w-ofmonsters-and-men/] Accessed $17^{\text {th }}$ February 2016

Kong L 1995 Popular music in geographical analyses Progress in Human Geography 19 183-198

Kong L 1997 Popular music in a transnational world: the construction of local identities in Singapore Asia Pacific Viewpoint 38 19-36

Lanham T 2015 of Monsters and Men carry on folk traditions $16^{\text {th }}$ October [http://www.sfexaminer.com/of-mos/] Accessed 10 ${ }^{\text {th }}$ August 2017 
Leyshon A Matless D and Revill G 1995 The Place of Music: [Introduction] Transactions of the Institute of British Geographers 20 423-433

Manganelli G 2006 L'Isola Pianeta e altri settentrioni Milano Adelphi

Mitchell T 2009 Sigur Rós's Heima: An Icelandic Psychogeography Transforming Cultures eJournal 4 $172-198$

Mitchell T 2013 New Zealand Glimpsed through Iceland: Music, Place and Psychogeography Musicology Australia 35 41-65

Mossman K 2012 Of Monsters and Men: 'We found we could bond better by telling each other fairytales' The Guardian Sunday $12^{\text {th }}$ August [http://www.theguardian.com/music/2012/aug/12/ofmonsters-men-mossman-interview] Accessed $15^{\text {th }}$ January 2016

Muhlenberg D 2016 Of Monsters and Men interview 31 $1^{\text {st }}$ May 2016

[https://superbalist.com/thewayofus/2016/03/31/of-monsters-and-men-interview/568] Accessed $10^{\text {th }}$ August 2017

Mundal E and Wellendorf J 2008 (Eds) Oral Art Forms and their Passage into Writing Museum Tusculanum Press University of Copenhagen ISBN: 9788763505048

Nevarez L 2013 How Joy Division Came to Sound Like Manchester: Myth and Ways of Listening in the Neoliberal City Journal of Popular Music Studies 25 56-76

Neijmann D 1997 The Icelandic Voice in Canadian Letters: The Contribution of Icelandic-Canadian Writers to Canadian Literature McGill-Queen's Press ISBN 978-0-88629-317-8 
Oslund K 2002 Imagining Iceland: Narratives of Nature and History in the North Atlantic The British Journal for the History of Science 35 313-334

Prior N 2015 'It's a Social Thing, Not a Nature Thing': Popular Music Practices in Reykjavík, Iceland Cultural Sociology 9 81-98

Revill G 2000 Music and the politics of sound: nationalism, citizenship, and auditory space Environment and Planning D: Society and Space 18 597-613

Revill G 2005 Vernacular culture and the place of folk music Social and Cultural Geography 6 693706

Said E 1978 Orientalism Pantheon Books New York

Sigurõardóttir M and Young T 2011 Towards Creative Iceland: Building Local, Going Global: Quantitative and Qualitative Mapping of the Cultural and Creative Sectors in Iceland Various May 2011

Simpson J 2004 Icelandic Folktales and Legends (Revealing History) The History Press

Smith S 1994 Soundscape Area 26 232-240

Smith S 1997 Beyond geography's visible worlds: a cultural politics of music Progress in Human Geography 21 502-529

Strmiska M 2000 Ásatrú in Iceland: The Rebirth of Nordic Paganism? Nova Religio: The Journal of Alternative and Emergent Religions 4 106-132

Sullivan P 2003 Waking up in Iceland London Sanctuary 
Tuan, Y F 1979 Space and place: Humanistic perspective. In S. Gale \& G. Olson Eds, Philosophy in Geography Dordrecht: D. Reidel

Tuan, Y F 1991 Language and the making of place Annals of the Association of the American Geographers 81 684-696

Webb P and Lynch J 2015 "Utopian Punk": The Concept of the Utopian in the Creative Practice of Björk Utopian Studies 21 313-330

Zarrilli L 2011 Iceland and the Crisis: Territory, Europe, Identity Revista Romana de Geografie Politica 1 5-15 